\title{
Market-based instruments for risk-averse farmers: rubber agroforest conservation in Jambi Province, Indonesia
}

\author{
UTKUR DJANIBEKOV \\ Institute for Food and Resource Economics (ILR), University of Bonn, \\ Meckenheimer Allee 174, 53115, Bonn, Germany. Tel: +49-228-732892. \\ Email:u.djanibekov@ilr.uni-bonn.de \\ GRACE B. VILLAMOR \\ Center for Development Research (ZEF), University of Bonn, Germany. \\ Email:gracev@uni-bonn.de
}

Submitted 28 November 2015; revised 16 June 2016, 15 August 2016; accepted 21 September 2016; first published online 1 December 2016

\begin{abstract}
This paper investigates the effectiveness of different market-based instruments (MBIs), such as eco-certification premiums, carbon payments, Pigovian taxes and their combination, to address the conversion of agroforests to monoculture systems and subsequent effects on incomes of risk-averse farmers under income uncertainty in Indonesia. For these, the authors develop a farm-level dynamic mean-variance model combined with a real options approach. Findings show that the conservation of agroforest is responsive to the risk-aversion level of farmers: the greater the level of risk aversion, the greater is the conserved area of agroforest. However, for all risk-averse farmers, additional incentives in the form of MBIs are still needed to prevent conversion of agroforest over the years, and only the combination of MBIs can achieve this target. Implementing fixed MBIs also contributes to stabilizing farmers' incomes and reducing income risks. Consequently, the combined MBIs increase incomes and reduce income inequality between hardly and extremely risk-averse farmers.
\end{abstract}

\section{Introduction}

Indonesia has the second largest area of deforestation in the world (Margono et al., 2012). As few primary forests remain in the country, conserving rubber agroforestry systems in the lowlands has been proposed as a means of maintaining ecosystem services (Tomich et al., 2004; Villamor et al.,

The authors are grateful for the support of the Landscape Mosaic and REDDALERT projects implemented by ICRAF. They also thank two anonymous reviewers and Dr Guido Lüchters for their helpful comments in developing the paper. 
2014a). Due to their inclusion of multiple trees and sub-canopy species and similar structure to natural secondary forests, rubber agroforests serve as surrogate ecosystems for hosting lowland biodiversity, which was formerly found in lowland primary forests (Tata et al., 2008; van Noordwijk et al., 2014). However, rubber agroforests have low economic returns and thus are rapidly being converted to more profitable monoculture production systems such as oil palm and rubber (Villamor et al., 2014b).

Market-based instruments (MBIs) are policy tools that can be used to increase the financial benefits of rubber agroforests or sanction their conversion, and could make agroforests economically competitive with monoculture systems in order to conserve them. Several studies have analyzed MBIs in the context of forest landscapes (Wunder, 2008). Based on the farm survey conducted in Sumatra, Indonesia by Cacho et al. (2014), the majority of respondents indicated that they were willing to forgo the conversion of forest to oil palm if rewards for carbon (C) stocks in forests were available. However, they concluded that, depending on opportunity cost of land, C payments to farmers need to be substantial in order to provide an economic incentive for maintaining forest. Eco-certification schemes are another type of MBI that provide additional subsidies for the sustainable use of natural resources. According to Blackman and Naranjo (2012), participation in some eco-certification schemes has led to increased adoption of more sustainable farming practices. On the contrary, a study by MartínezSánchez (2008) revealed that participation in agricultural eco-certification schemes by farmers failed to improve environmental indicators relative to farms that use conventional practices. Aside from $\mathrm{C}$ storage and ecocertification schemes, the most common example of MBI is the tax (i.e., Pigovian tax) for unsustainable land-use practices that contribute to ecosystem degradation. For example, Koskela et al. (2007) showed that a harvest tax for conserving forest biodiversity in Finland motivates farmers to retain trees. However, there are few similar cases found in developing countries because most farmers in such countries are poor and consequently such taxes may have adverse impacts on their livelihoods. Thus, when implementing MBIs it is also necessary to consider heterogeneous farmers that might benefit and be adversely affected by such initiatives.

Uncertainty about the effects of MBIs is exacerbated by risks associated with land-use incomes. The risk inherent in the uncertainty of future returns can be a barrier to the conservation practices that yield long-term results (Koundouri et al., 2006). A multitude of models have been developed in order to address land use and land-use change under uncertainty and risk (Hardaker et al., 2004). Castro et al. (2013), using the mean-variance model, concluded that MBI rewards need to be given to farmers for conserving environmental land use, and the derived MBI values based on the farm-level model would be almost half of the values based on opportunity cost analysis. The difference in derived MBI values is likely due to resource constraints in the farm-level model and the fact that the fixed MBI payments allow farmers to receive certain revenues and reduce income variance. At the same time, Djanibekov and Khamzina (2016), using the expected utility model, showed that under conditions of risk agroforestry can be a preferable land-use option for farmers 
even without MBI incentives. Similarly, Ramirez et al. (2001), applying the downside risk model, revealed that agroforestry brings higher expected incomes and lower risk levels than monoculture. This is because agroforestry reduces the negative effects of farm income risks by including multiple land uses that have little variability and correlation and, with increasing risk aversion, a farmer prefers more land-use diversification with agroforestry (Baumgärtner and Quaas, 2010). However, these models do not address the temporal decision making of farmers. The optimal stopping approach allows us to determine the best time to stop a certain activity and is mainly used in forest harvest problems to show possible time prolongation for such decisions (e.g., Alvarez and Koskela, 2006). With the real options approach, we can address fully the intertemporal flexibility and analyze how a farmer at each decision point considers whether to make land-use investments now or later, as well as when to conduct harvesting and rotation strategies (Musshoff, 2012; Regan et al., 2015). Frey et al. (2013) showed that, when considering the intertemporal flexibility in landuse decisions under uncertainty, the benefits of annual crops outweigh the benefits of agroforestry. Engel et al. (2015), using the real options approach, examined landowners' decisions to conserve forest under MBI payments, and revealed that the low opportunity cost delays the land-use change and that the payment amount is highly correlated with the volatility of land uses. Kassar and Lasserre (2004) evaluated biodiversity conservation, considering its irreversibility and uncertain values, and showed that the real options approach allows consideration of the change in species diversity over time.

To our knowledge there are few studies that have used the real options approach to analyze environmental land issues within the farm-level context and that consider multiple MBIs and heterogeneity in the risk attitudes of farmers. In this study, we fill this niche by incorporating the real options approach into the farm-level dynamic mean-variance programming model to consider flexibility in farming decisions over time and accordingly develop MBIs that prevent heterogeneous risk-averse farmers from converting agroforest into monoculture systems under uncertainty. The overall objective of our study is to address the above-mentioned research gaps. The specific objectives are to: (1) identify MBIs and their values that are appropriate for addressing the land conversion issues under temporal flexibility of decision making as well as uncertainty of income; and (2) investigate the effects of different MBI policies on the livelihoods of farmers with different risk-aversion levels under conditions of income uncertainty.

\section{Methods}

\subsection{Study area}

The study area is the Jambi province of Sumatra in Indonesia, which is one of the centers of deforestation in Indonesia. The remaining primary forests on the island are mostly found in protected areas. Agroforests continue to be the dominant land use in the study area and, due to the near absence of primary forest, have become the most important reservoirs 
of the remaining lowland biodiversity (Tata et al., 2008). Due to their lower profitability relative to other land uses, particularly in the lowlands, farmers have been converting rubber agroforest (hereafter referred to as agroforest) to oil palm and rubber monoculture plantations (Budidarsono et al., 2012).

The majority of farmers are small scale with an average area of 4 ha (Villamor, 2012). Aside from agroforest, the main land uses of farmers in the study area are rice, oil palm and rubber monoculture. Agroforests include fruit trees such as jengkol (Archidendron pauciflorum), petai (Parkia speciosa) and durian (Durio zibethinus), as well as other tree species. Rice is the primary staple food and is usually cultivated on fields adjacent to households. The typical rotation cycles of both oil palm and rubber monoculture systems range from 30 to 40 years (Villamor, 2012). The most profitable land use is oil palm (Budidarsono et al., 2012). Land-use incomes are subject to risk and uncertainty, mainly stemming from the variability of crop yields and prices (Purnamasari et al., 2002). Yield fluctuations can result from weather variability, fires, limited local knowledge of appropriate management practices, and pest and disease outbreaks. Prices may vary due to unpredictable changes in currency exchange rates, seasonality and fluctuations in global markets. Online appendix, table A1, available at https://doi.org/10.1017/S1355770X16000310, presents the mean and coefficient of variation of the yields and prices of land uses.

\subsection{Simulated variability of prices and yields}

Following Knight (1921), we define uncertainty in our study as imperfect knowledge and risk as uncertain outcomes, especially unfavorable outcomes. We employ a geometric Brownian motion approach with drift to examine the effects of fluctuations in crop prices over time. This is a stochastic process with independent increments and change occurring in the process during any period and is expected to be normally distributed (Dixit and Pindyck, 1994). Accordingly, we assume that prices are subject to the following stochastic process:

$$
p_{j n t}=p_{j 0} \exp \left(\left(\mu_{j}-\frac{\sigma_{j}}{2}\right) t+\sigma_{j} w_{j n t}\right),
$$

where $p_{\text {jnt }}$ is the price of crop with the geometric Brownian motion path over the years $t(1,2, \ldots, T$, where $T=59)$ under different states of nature $n ; p_{j 0}$ is the initial value of crop prices; $w$ represents Brownian motion; $\mu$ is the percentage of drift (constant); and $\sigma$ is the percentage of volatility of land-use prices (constant). Information on drift and volatility of prices and average and standard deviation of net present values of crops is given in online appendix, table A2, and information on simulated prices is given in online appendix, figure A1.

To capture variability in yields, we use the information on average crop yields reported between 2001 and 2010 and consider their percentage deviations from mean yield over these years. We assume that percentage deviations of crop yields are identical over the period of analysis and include them into the production timeline of crops. We also assume that the yield variability of jengkol, petai and durian follows the magnitude of yield 
variability of rubber agroforest. Crop yields of monoculture crops differ over the years and depend on their period of establishment and replacement (see online appendix, figure A2). Yields of agroforestry are assumed to be constant over the years, because such land use is a secondary forest and has natural regrowth. Due to the absence of long-term data on input production costs, their uncertainty is not considered. We consider 10 paths for prices and 10 variability levels for yields, which gives in total 100 simulations. This number of simulations is selected due to the time required to run the model; an increase in number of simulations substantially increases the time needed to finalize the model run.

Moreover, when considering the stochastic process and variability for crop prices and yields, respectively, we do not include their correlations in our analysis. Thus, we assume that prices and yields are not correlated and there is no correlation of these parameters among land uses. These simplifications are due to the complexity of modeling the correlation of several stochastic processes of prices with variability of yields.

\subsection{The model}

We apply a single farm-level model that considers different risk-aversion levels. In this way, we can address issues such as income, farming system complexities (e.g., interactions between crops and resource usage), longterm comparisons (e.g., option to convert, rotate), and preferences (e.g., relative attitudes regarding risk). The model is programmed in GAMS ${ }^{1}$ and is available on request. In the model we assume that a farmer faces the problem of selecting annual crops (e.g., rice), and whether or not to convert agroforest into alternative perennial crops (e.g., oil palm and rubber monoculture) under conditions of income uncertainty. To model the degree of risk aversion of farmers and farm planning processes over the years, we develop the dynamic mean-variance programming model that combines the real options approach. In this model, if land uses have the same returns (or variances) but one land use has lower variances (or higher expected return), then this land use is preferred by the farmer.

The objective function can be expressed as a dynamic programming equation in terms of the optimal value:

$$
C E_{t}=\max \left(\left(E(I)_{t}-R P_{t}\right)+C E_{t+1}\right),
$$

where the objective is to maximize the sum of farm certainty equivalents $(C E)$ of each year. The CE represents the certain income level that is rated by a farmer equivalent to an uncertain income level, and includes an annual expected income value $(E(I))$, which is reduced by the annual risk premium $(R P)$ over years $(t)$, i.e., $E(I)_{t}-R P_{t}$. Hence, the $C E$ allows the consideration of risk aversion of a farmer. In this equation, $C E_{t}$ represents the optimal certainty equivalent of the objective function throughout the remaining planning period under optimal decisions. The model is solved for each stage, $T-1, T-2, \ldots, 1$, and permits us to determine $C E_{t}$ once $C E_{t+1}$ is known.

${ }^{1}$ General Algebraic Modeling System (www.gams.com). 
The income of a farmer varies with respect to crop yields and prices, and each outcome has the same probability and number of states of nature. We calculate farm incomes under different states of nature as follows:

$$
I_{n t}= \begin{cases}\frac{\sum_{j}\left(p_{j n t} M_{j n t}-c_{j t} X_{j t}\right)}{(1+d)^{t}} & \text { where } t \leq 30 \\ \frac{\sum_{j}\left(p_{j n t} y_{j n t}-c_{j t}\right) X_{j 30}}{(1+d)^{t}} & \text { where } t>30,\end{cases}
$$

where $I$ corresponds to the farm income over the years under different states of nature, $p$ and $y$ are crop prices and yields, respectively, $M$ is the sale amount of crops as not all crop outputs are assumed to be sold in the market and some are used for household consumption (see equation (16)), $c$ is the establishment and management costs, $X$ is the area of crops, and $d$ is the discount rate. We consider that the costs of monoculture crops include initial sunk costs occurring in the period when monoculture crops are established, and costs for managing such land uses occurring in subsequent periods. The terminal values (i.e., the second term of the equation where $t>30$ ) include discounted net returns from land uses and MBIs, which occur beyond the modeled period and thus depend on the area of land uses in the last modeled period. Hence, the model does not simulate decision and state variables beyond 30 years. We use the terminal values of land uses due to the multiple rotations of oil palm and rubber monoculture which may signify crop benefits and costs occurring outside the modeled period. The maximum length of period that terminal values can include is 29. For example, if agroforest is converted into monoculture crops in the last modeled period, i.e., year 30, then land uses have the same area for the next 29 years, i.e., years 31-59. We include three discount rates (i.e., 5, 10 and 15 per cent), which are similar to rates used in previous studies in the region (e.g., Budidarsono et al., 2012; Villamor et al., 2014b). To simplify the interpretation of results, we focus on the model output with a discount rate of 10 per cent.

We include in the model a risk premium $(R P)$ in order to investigate the response of a farmer to risk. The risk premium is the minimum amount of money needed to motivate a farmer to select a relatively risky land use. The risk premium is defined in the model as:

$$
R P_{t}=0.5 V_{I_{t}}^{2} \frac{\gamma}{E(I)_{t}},
$$

where $V_{I_{t}}^{2}$ is the annual variance of discounted farm income, and $\gamma$ is the coefficient of the relative risk aversion of the farmer. We use the riskaversion coefficients ranging from 0.5 (hardly risk-averse) to 4.0 (extremely risk-averse) (as suggested by Anderson and Dillon, 1992). The more riskaverse the farmer is, the more $\mathrm{s} /$ he prefers land uses with lower income variability relative to alternative land uses that may provide greater income but are associated with greater variability (Anderson and Dillon, 1992). We use the constant relative risk aversion that includes a decrease in absolute risk aversion resulting from farm income increases. 
Because a farmer faces financial constraints, we assume that farm discounted expenditures cannot exceed the funds available for the farmer, which is formalized as:

$$
\begin{array}{ll}
\frac{g_{t}}{(1+d)^{t}} \geq \frac{\sum_{j} c_{j t} X_{j t}}{(1+d)^{t}} & \text { where } t=1 \\
S_{n t-1} \geq \frac{\sum_{j} c_{j t} X_{j t}}{(1+d)^{t}} & \text { where } 1<t \leq 30 \\
\sum_{t} \frac{\sum_{j} p_{j n t} y_{j n t} X_{j 30}}{(1+d)^{t}} \geq \sum_{t} \frac{\sum_{j} c_{j t} X_{j 30}}{(1+d)^{t}} & \text { where } t>30,
\end{array}
$$

where $g$ is assumed to be US $\$ 1,000$ and corresponds to the funds available in the initial year (i.e., initial state of funds at farm), and $S$ is the savings of a farmer from the previous year under different states of nature. Equation (7) states that summed land-use expenses occurring outside the modeling period (i.e., discounted costs at the terminal period) cannot be higher than summed returns during that period (i.e., discounted revenues at the terminal period).

We model farm savings over 30 years, due to the fact that the model does not simulate decision and state variables beyond this period. We assume that farm saving cannot be used for other purposes than agricultural production because we lack the necessary information on expenditure share of households depending on their risk aversion levels. The farm savings variable depends on funds available in the first year of the model (i.e., initial state of funds), income in current year and savings from previous years as follows:

$$
\begin{array}{ll}
S_{n t}=\frac{g_{t}}{(1+d)^{t}}+I_{n t} & \text { where } t=1 \\
S_{n t}=I_{n t}+S_{n t-1} & \text { where } 1<t \leq 30 .
\end{array}
$$

We assume the agroforest area to be 3 ha in the initial year. This agroforest area or any fraction of it can be converted to oil palm and rubber monoculture and this is irreversible. The agroforest area in the present period is the remaining agroforest area after conversion to monoculture crops, and thus the area of monoculture crops is the converted agroforest area in this and previous periods, which are determined as:

$$
\begin{aligned}
& \sum_{j} a_{j t}-W_{t}=\sum_{j} X_{j t} \quad \text { where } j=\text { agroforest, } t=1 \\
& \sum_{j} X_{j t-1}-W_{t}=\sum_{j} X_{j t} \quad \text { where } j=\text { agroforest, } 1<t \leq 30 \\
& \sum_{j} X_{j t-1}+W_{t}=\sum_{j} X_{j t} \quad \text { where } j=\text { oil palm and rubber monoculture, } \\
& t \leq 30
\end{aligned}
$$


where $a$ is the initial state of agroforest area (i.e., 3 ha), and $W$ includes the annual area of agroforest converted into monoculture crops. To consider the flexibility of farmers' decisions regarding the use of agroforest area over time at the whole-farm level, we include the real options approach in the dynamic mean-variance programming model. We use several forms of flexibility such as: maintaining agroforest or converting to monoculture crops in the initial period, delaying the conversion of agroforest to monoculture crops, retaining the area of converted monoculture crops, and maintaining monoculture crop production with rotations implemented over time. Oil palm and rubber monoculture can be planted and rotated over 30 years. In addition to multiple rotations, the use of monoculture crop types can change (i.e., rubber monoculture can be converted to oil palm or vice versa). We assume the maximum rotation cycle of oil palm and rubber monoculture systems to be 30 years. The model considers crop yield and establishment and management costs depending on the land-use decisions of a farmer over the modeled period. A combination of the real options approach with the mean-variance farm-level model allows us to consider the land-use investments and resource availabilities in the temporal decision making of a risk-averse farmer. By combining these two approaches at the whole-farm level, we take into account that a risk-averse farmer makes a single choice for land uses in each year while considering different crop prices and yield levels with respect to crop production and household consumption constraints.

An area constraint also includes the allocation of 1 ha of land (the land adjacent to the farm household) for rice production, as follows:

$$
\sum_{j} X_{j t} \leq b_{t} \quad \text { where } j=\text { rice, } t \leq 30
$$

where $b$ is the land area available to the household for rice cultivation.

Labor availability is another vital input for the land-use decisions of farmers. Labor is required during planting or conversion of crops and harvest of yield. The labor demand of a farm varies depending on crop yields. Most of the labor in Jambi is based on family labor (Villamor, 2012). We assume the labor use to be subject to the constraint of household labor availability, which is 2.7 individuals or 709 work days in the first year (Budidarsono et al., 2010). The availability of household labor grows at an annual rate of 1.12 per cent, which is the observed population growth rate in Indonesia between 2000 and 2014 (World Bank, 2015). The farm labor demand constraint needs to satisfy labor use during the land-use modeling period of 30 years and required beyond (i.e., terminal period), which are included in the model as follows:

$$
\begin{array}{ll}
\sum_{j} k_{j t} y_{j n t} X_{j t} \leq l_{t} & \text { where } t \leq 30 \\
\sum_{t} \sum_{j} k_{j t} y_{j n t} X_{j 30} \leq \sum_{t} l_{t} & \text { where } t>30,
\end{array}
$$


where $k$ and $l$ are, respectively, the labor demand for land-use activities and labor availability at the farm.

As the model considers a small-scale farm, we assume that the farmer sells outputs of crops and rice production needs to satisfy the rice consumption of household members. We further assume that there are no alternative sources (e.g., market, neighbors, government assistance) to meet the household's rice demand. Accordingly, we consider a balance equation for crops over the period of 30 years (because the model does not simulate decision variables beyond 30 years) during which outputs of crops are sold in the market, except rice output that needs to be consumed and the surplus marketed:

$$
y_{j n t} X_{j t}=h_{j t}+M_{j n t} \quad \text { where } h_{j}=\text { rice, } t \leq 30,
$$

where $h$ is the rice consumption requirement of household members, which we assume to be $200 \mathrm{~kg}_{\text {capita }}{ }^{-1}$.

\subsection{Market-based instrument scenarios}

We consider MBIs that can take the form of rewards for ecosystem services provided by agroforest such as rubber and $C$ storage, and sanctions on a farmer for emitting $C$ from conversion of agroforest to monoculture systems. For the MBI scenarios we determine the values of rewards and punitive taxes based on two approaches: (1) by simulating different fixed amount price scenarios; and (2) annually varying opportunity cost of agroforest at farm. To evaluate various reward and tax schemes, we use the following five scenarios in the model:

(1) A business-as-usual (BAU) scenario, without any MBI interventions.

(2) An eco-certification (eco-certification) scenario, in which MBIs are in the form of price premiums that are provided to risk-averse farmers based on the harvested output from agroforests. The revenues from eco-certification vary according to rubber yields and can be received every year. We consider eco-certification premiums of 7 (based on the 1 per cent of rubber price premium suggested by Leimona, 2010), US\$50, 300, 1,000 and 1,800 $\mathrm{t}^{-1}$ year $^{-1}$. To find the range of MBI values, we conducted the sensitivity analysis with respect to MBI values and analyzed the agroforest area maintained under each value. We also calculate the eco-certification premium based on the opportunity cost of agroforest with regard to the annual discounted net returns of oil palm and rubber monoculture. When deriving ecocertification value considering the opportunity cost, its value differs every year depending on states of nature.

(3) A payment for the $C$ sequestration (carbon) scenario, in which payments are conditional on the amount of $C$ stored in the woody biomass on agroforest plots managed by a farmer. The returns from stored $C$ are uncertain due to the variability of $C$ stocks. The payments for $C$ sequestration can only be provided to a farmer in years $5,15,20,25,30$ and every five years in the terminal period of the model. This time interval is similar to C forestation projects (e.g., 
Clean Development Mechanism; see Peters-Stanley et al., 2012). In order to analyze the effects of $C$ prices on farming activities, we evaluate $\mathrm{C}$ payment levels of US\$5-50 $\mathrm{tCO}_{2}^{-1}$. For the simplicity of the analysis we present $C$ payment levels of 5 (a similar $C$ sequestration payment level to the one observed by Peters-Stanley et al., 2012), US\$15, 20, 30 and $50 \mathrm{tCO}_{2}^{-1}$. We also derive the $\mathrm{C}$ sequestration payment level needed to maintain agroforest based on its opportunity cost, which varies depending on states of nature.

(4) A Pigovian tax (Pigovian tax) scenario, in which a tax is levied on individual farmers for $\mathrm{C}$ emitted as a result of converting agroforest to oil palm and/or rubber monoculture. The $C$ emission levels vary according to differences in $C$ stocks among perennial crops and agroforestry systems. In this scenario, we consider tax levels similar to the C payments (i.e., ranging from US\$5 to 50), and thus we present five different tax levels to analyze their effects on farming activities (i.e., US\$5, 15, 20, 30 and $50 \mathrm{tCO}_{2}^{-1}$ ). The taxes are levied on risk-averse farmers at the time of the conversion of agroforest to monoculture crops and every five years afterwards (i.e., similar to the rewards period in C forestation projects (Peters-Stanley et al., 2012)). Similarly to the previous two MBI scenarios, we also derive a Pigovian tax value according to the farm opportunity cost of agroforestry.

A combination (combined) scenario which includes all of the abovementioned MBIs and their corresponding periods of payments and taxes.

\subsection{Data sources}

We obtain farm household-specific data from the study of Villamor (2012). This data set includes farm production and household characteristics of 95 farm households surveyed in the study area between February and March 2010. Household- and model-specific parameters are given in table A3 in the online appendix. We use yield production data of major land uses from the World Agroforestry Centre (Budidarsono et al., 2010). We consider two types of information for crop yields: (1) crop yields over the growing period of crops that also includes the assumed maximum production timeline, i.e., rotation cycle, of 30 years of monoculture crops (see online appendix, figure A2; Budidarsono et al., 2010); and (2) data for the period between 2001 and 2010 on reported average crop yields in the province to include crop yield variability (Center for Statistics Bureau of Bungo District, 2012; Ministry of Agriculture of Indonesia, 2012). The farm household yields of durian, jengkol and petai include information from surveys, and we assume that their variability corresponds to the level of variability of rubber agroforest. The production inputs differ depending on crop type, but they are fixed for each crop, except for labor input which varies depending on the crop yield. We also use data on prices and yields from the Center for Statistics Bureau of Bungo District (2012) and the Ministry of Agriculture of Indonesia (2012). The crop output price data for periods between 2001 and 2010 are further used to calculate the drift and volatility of prices to generate the geometric Brownian motion of prices. In terms of the C stocks 
associated with major land uses, we obtain data from Rahayu et al. (2005). We do not consider change in crop composition over time by management practices due to the absence of such information.

\section{Results}

\subsection{Land-use change and market-based instruments}

Prior to introducing sustainable land-use policies, it is important to investigate the land-use change when the current settings continue (i.e., BAU scenario). Under the BAU scenario, the hardly risk-averse farmer immediately converts about 0.8 ha of agroforest to oil palm (figure 1a). Such a risk-averse farmer gradually replaces agroforest with oil palm and, in year 24 , the area of agroforest is entirely converted to oil palm. The gradual land-use change is due to the labor constraint and increase in funds available for monoculture production. During the land-use change process, the hardly risk-averse farmer selects different oil palm rotations. Although oil palm has highly varying returns, the preference for oil palm stems from its relatively higher profitability than other crops and a low-risk attitude of farmers. Between years 11 and 20, to concentrate resources for managing oil palm, the hardly risk-averse farmer limits rice cultivation but produces a sufficient amount to meet household consumption.

In contrast, the extremely risk-averse farmer considers land uses that have lower income risks while trying to generate the highest income (figure 1b). Although agroforest is less lucrative than alternative crops, the extremely risk-averse farmer prefers to maintain some area of agroforest to diversify farming and hedge risk via low variability of its returns. At the same time, establishing some area of oil palm and rubber monoculture also diversifies land-use incomes and may reduce the risks of this farmer. Hence, in the early stages of the analyzed period, the farmer changes some agroforest area to both monoculture crops, i.e., oil palm

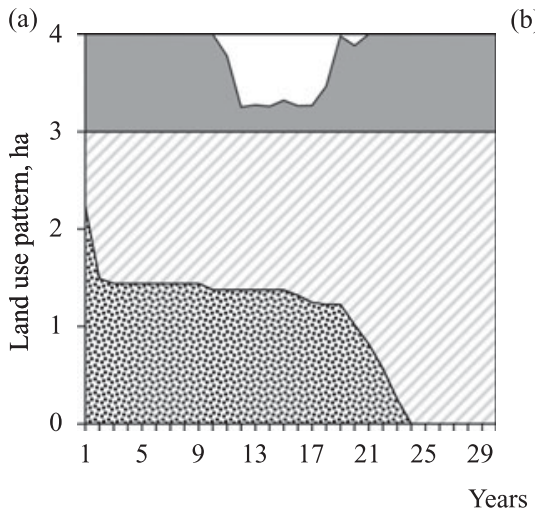

(b)

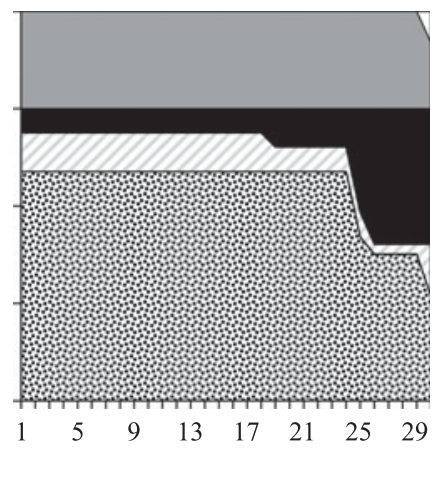

由 Agroforest $\square$ Oil palm

- Rubber monoculture

$\square$ Rice

$\square$ Fallow land

Figure 1. Land-use pattern among hardly (a) and extremely (b) risk-averse farmers in the business-as-usual scenario over 30 years at a discount rate of $10 \%$ 


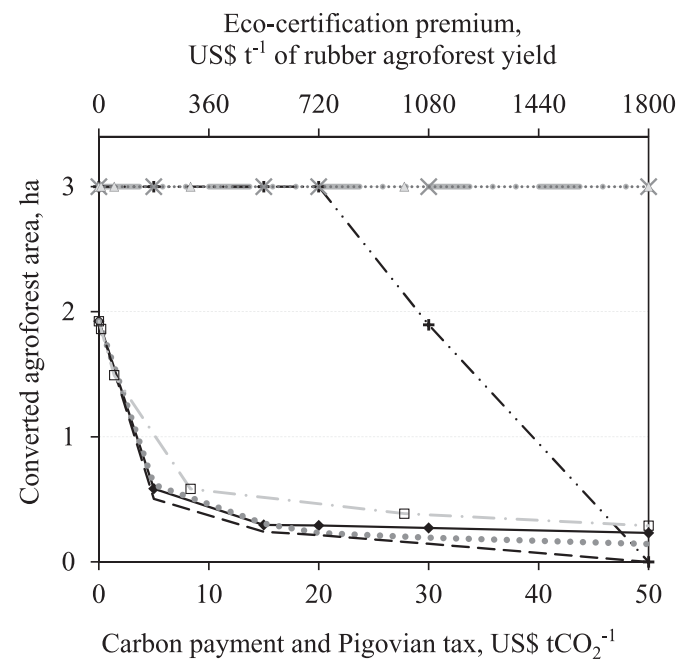

Hardly risk-averse

farmer:

…....... Eco-certification

- Carbon

$\times$ Pigovian tax

-+- Combined

Extremely risk-averse farmer:

$-\square-$ Eco-certification

$\longrightarrow$ Carbon

..... Pigovian tax

- - - Combined

Figure 2. Agroforest area converted to oil palm and rubber monoculture plantations by hardly and extremely risk-averse farmers under different market-based instruments over 30 years at a discount rate of $10 \%$

Note: Initial agroforest area is $3 \mathrm{ha}$.

and rubber monoculture, and in the last period (i.e., terminal period) the farmer maintains 1.1 ha of agroforest. Due to lower profit variability of rubber monoculture relative to oil palm, from year 19 and onwards, the extremely risk-averse farmer replaces oil palm with rubber monoculture. In the last year, due to consideration of the terminal period, the model shows an increase in oil palm area at the expense of reduced rice area.

With respect to the discount rates, under the BAU scenario, at 5 per cent both the hardly and the extremely risk-averse farmers completely convert agroforest area to monoculture crops (online appendix, figure A3). At a discount rate of 15 per cent, the hardly risk-averse farmer still changes agroforest area to monoculture crops, whereas the extremely risk-averse farmer conserves about 2.5 ha of agroforest. Furthermore, the higher the discount rate is, the more the extremely risk-averse farmer prefers oil palm instead of rubber monoculture.

Eco-certification premiums, C payments and Pigovian tax do not prevent the hardly risk-averse farmer from changing agroforest to monoculture crops (figure 2). However, individually these instruments reduce the conversion rate of agroforest in comparison to the BAU scenario. The lowest rate of land-use conversion is in the Pigovian tax scenario, followed by the C payment. Only the combination of MBIs, and at their higher levels, stops the land-use change of the extremely risk-averse farmer. On the contrary, even at the low levels of MBIs the extremely risk-averse farmer has a higher area of agroforest than without MBIs. For instance, the US $\$ 5 \mathrm{tC}^{-1}$ payment for $\mathrm{C}$ stored in agroforest reduces the land-use change rate over the years and augments the maintained area of agroforest by 1.3 ha more than without such payment. At lower MBI values, the $C$ payment is the 
most effective instrument to address land-use conversion. When considering higher MBI values, the application of Pigovian tax is the most efficient $\mathrm{MBI}$, because the high level of taxes increases the costs of the extremely risk-averse farmer which s/ he may not be able to cover. However, individually, none of the MBI policies leads to conservation of the entire area of agroforest (i.e., $3 \mathrm{ha}$ ); only combinations of different instruments achieve such a target. Additional returns from rubber eco-certification and payments for $C$ storage of agroforest outweigh revenues from monoculture crops, and high taxes on monoculture crops also reduce their profitability. In addition, such effects of MBIs on the farmer are due to the assumption that MBI values are fixed and lead to certain revenues or costs. Hence, the higher the risk perception of the farmer is, the higher are the effects of MBIs. For all risk-averse farmers, the combination and higher values of MBIs conserve agroforest. When considering different discount rates, the combined MBI scenario conserves the largest area of agroforest at 15 per cent discount rate, whereas at 5 per cent discount rate the MBIs are less efficient due to the low discounting of long-term profits from monoculture crops (online appendix, figure A4).

Substantially higher rewards and taxes are needed to conserve agroforest when deriving MBI values according to the opportunity cost of agroforest (online appendix, figure A5). These reward and tax levels are adjusted based on the variability of net returns from oil palm and rubber monoculture, and consequently their values increase income variance.

\subsection{Carbon storage and market-based instrument benefits}

Without MBI the provision of ecosystem services from agroforests is substantially reduced (figure 3a). In almost all simulated MBI values, the hardly risk-averse farmer converts agroforest over the years to monoculture crops which leads to high $\mathrm{C}$ emissions. On the contrary, due to diversification of agroforest the extremely risk-averse farmer maintains some area of this land use and thus stores $C$ even without any MBI. Introduction of minor $C$ payments and Pigovian taxes can substantially improve provision of ecosystem services of this farmer. Of the individual MBIs, the Pigovian tax scenario is the most promising for addressing $C$ storage, whereas of all the scenarios, the combined scenario results in the greatest amount of $\mathrm{C}$ stock. The model results on $\mathrm{C}$ storage in agroforest under 5 and 15 per cent discount rates are given in online appendix, figure A6.

When analyzing costs and benefits from MBI, the hardly risk-averse farmer receives some payments from having agroforest before entirely converting it to monoculture crops (figure $3 \mathrm{~b}$ ). Such a risk-averse farmer can generate the highest returns in the combined scenario, followed by the $C$ payment and eco-certification premium scenarios. Despite its high levels, the taxes for $\mathrm{C}$ emissions do not result in high costs for the hardly riskaverse farmer. We can observe a similar trend for the extremely risk-averse farmer, yet the amount of revenues and costs from the MBI are, respectively, higher and lower than those of the hardly risk-averse farmer. This is because the extremely risk-averse farmer chooses less risky land use, i.e., maintains a large area of agroforest. The revenues from MBIs with the highest simulated reward and tax levels in the combined scenario are similar for 


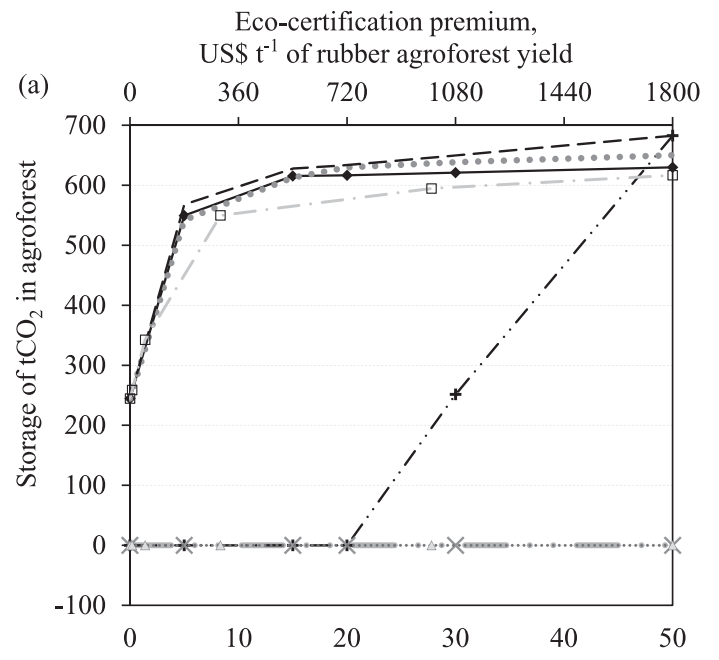

Hardly risk-averse

farmer:

…..... Eco-certification

- Carbon

$\times$ Pigovian tax

-+- Combined

Extremely risk-averse farmer:

- - Eco-certification

$\longrightarrow$ Carbon

..... Pigovian tax

- - - Combined

Carbon payment and Pigovian tax, $\mathrm{US} \$ \mathrm{tCO}_{2}{ }^{-1}$

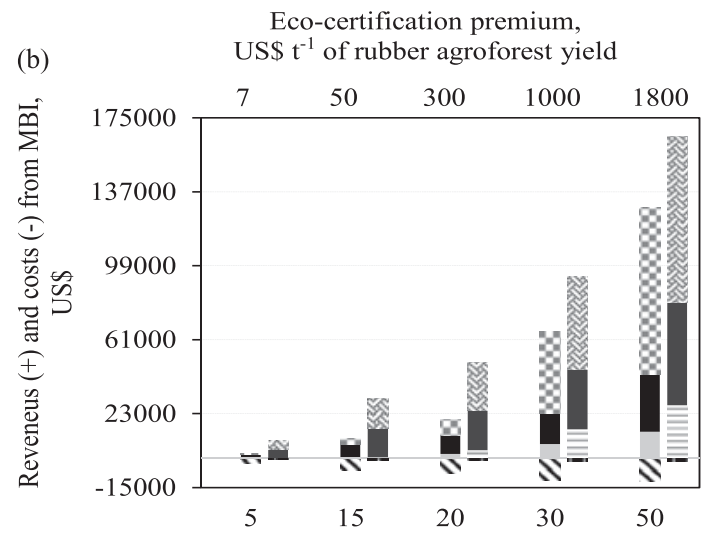

Hardly risk-averse farmer:

Eco-certification

- Carbon

$\checkmark$ Pigovian tax

Combined

Extremely risk-averse farmer:

$=$ Eco-certification

- Carbon

Pigovian tax

« Combined

Carbon payment and Pigovian tax, US $\$ \mathrm{tCO}_{2}^{-1}$

Figure 3. Storage of $\mathrm{tCO}_{2}$ in agroforest (a), and revenues and costs from market-based instruments (b), for hardly and extremely risk-averse farmers over 30 years at a discount rate of $10 \%$

both risk-averse farmers. At increased discount rate the revenues and costs from MBIs reduce, while at reduced discount rate the revenues and costs from MBIs increase (online appendix, figure A7).

The derived MBI values according to the opportunity cost of agroforest result in larger total returns and taxes than when MBI have fixed values over the years. For example, the C payments range from US $\$ 3,290$ to 262,850 for hardly risk-averse farmers, whereas they range from US $\$ 2,170$ to 58,350 for extremely risk-averse farmers (compare summed values over years in the online appendix, figure A5). 


\subsection{Farm income}

The certainty equivalence (CE) of farmers differs among scenarios and the degree of risk aversion (figure 4). Under the BAU scenario, the hardly riskaverse farmer earns almost three times more income than the extremely risk-averse farmer. The few established areas of highly profitable and uncertain crops, i.e., oil palm, results in low incomes for extremely riskaverse farmers. The low levels of MBI do not substantially influence the $\mathrm{CE}$ of farmers. As MBI values increase, the income differences decrease between hardly and extremely risk-averse farmers. This is particularly true at the highest reward and tax levels in the combined scenario, where the CEs of hardly and extremely risk-averse farmers are US $\$ 117,100$ and 112,200 , respectively, over the period of analysis. High rewards and taxes of MBI lead to a decrease in the opportunity cost of agroforest, and their fixed values reduce income variability. In such case, both types of riskperceiving farmers mainly generate income from maintaining agroforest, which is more stable, and accordingly they have similar CEs. Comparing the combined and BAU scenarios shows that the extremely risk-averse farmer benefits substantially from MBIs (e.g., the income of the extremely risk-averse farmer increases by more than a factor of four, whereas the income of the hardly risk-averse farmer increases by a factor of one and a half). After the combined scenario, the $\mathrm{C}$ and eco-certification instruments result in the highest CEs, respectively. As expected, the Pigovian tax leads to a lower CE than in the BAU scenario, and reduces mainly the $\mathrm{CE}$ of the hardly risk-averse farmer that converts agroforest into monoculture crops. For instance, with the highest Pigovian tax levels, the CE of the extremely risk-averse farmer decreases by US\$4,000, whereas the CE of the hardly risk-averse farmer decreases by US\$33,000 (i.e., by almost a half) as compared to the BAU. At a 5 per cent discount rate, the CE is larger (by more than two times under the BAU scenario for both risk-averse farmers), and at a 15 per cent discount rate the CE is lower (by about onehalf under the BAU scenario for both risk-averse farmers) than the $\mathrm{CE}$ at 10 per cent (online appendix, figure A8). The trend of CE under different MBIs is similar at different discount rates.

\subsection{Risk management}

The risk-efficient points of each MBI policy scenario are presented in figure 5 with the expected and variance of income. The risk-efficient MBI policies for farmers result in high expected and low variance of income. Under the BAU scenario, both risk-averse farmers have one of the highest income variances but do not have the highest expected incomes. Hence, when the income risks are taken into account in rural development issues, the continuation of the BAU scenario may not be preferable. Among the MBI scenarios, the highest levels of eco-certification premium followed by $\mathrm{C}$ payment can be the riskiest instrument for hardly risk-averse farmers (although with the increase in expected incomes) because of continuous conversion of agroforest to monoculture systems. The expected income under the $C$ scenario with the lowest $C$ payment level is higher than incomes in the BAU and other MBI scenarios at their lowest values. Imposing a Pigovian tax results in lower expected and variance of income than in 


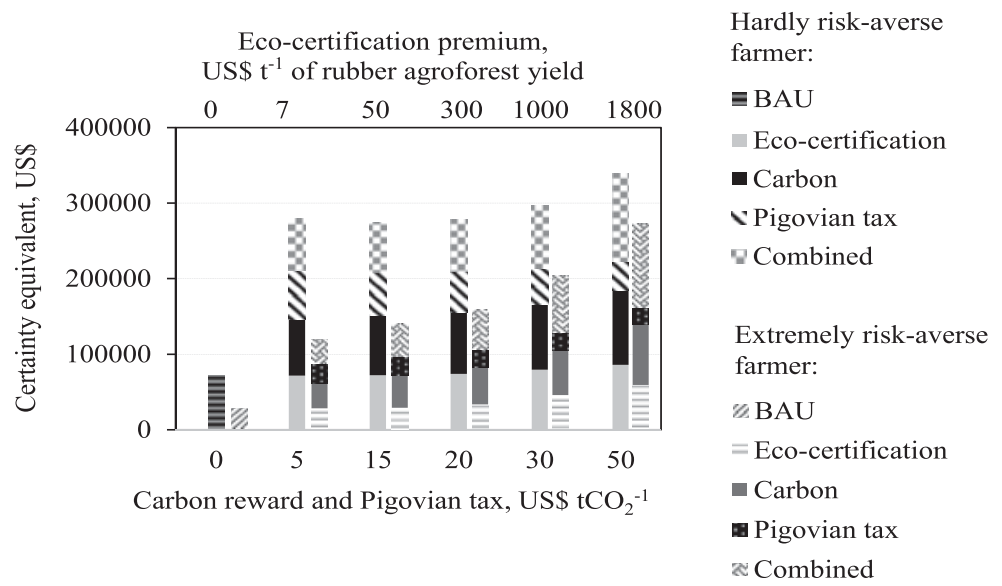

Figure 4. The cumulative discounted certainty equivalents of hardly and extremely risk-averse farmers over 30 years under the scenarios of business-as-usual (BAU) and market-based instruments

Note: Discount rate is $10 \%$.

the BAU, due to lower rate of agroforest conversion to monoculture crops that have high and varying profits. Such an MBI has substantial impacts on the extremely risk-averse farmer that is usually poor and susceptible to risks, and thus avoids income sanctions and prefers less uncertain income crops. In addition, due to aversion to future uncertainty from land uses, preference towards agroforest and fixed returns from MBIs, the income variance of the extremely risk-averse farmer is lower than that of the hardly risk-averse farmer. The hardly risk-averse farmer can have the lowest and close to the extremely risk-averse farmer income variability when the combination of highest values of MBIs operates. The highest MBI values in the combined scenario also bring the highest expected income for both risk-averse farmers.

At a 5 per cent discount rate the expected and variance of income are higher than the model output with a 10 per cent discount rate (online appendix, figure A9). Accordingly, at higher discount rates farmers have lower expected and variance of income.

\section{Discussion}

\subsection{Market-based instruments for conservation}

Without policy interventions the agroforest is likely to be converted to oil palm and rubber monoculture (Villamor and van Noordwijk, 2011; Villamor, 2012). Such land-use change increases greenhouse gas emissions, biodiversity loss and hydrological disturbance (Tomich et al., 2004). In addition, fluctuations in prices, yields and the supply of ecosystem services may pose risks that affect land-use decisions and the performance of policies intended for land-use sustainability. MBIs may reduce the rate 
(a)

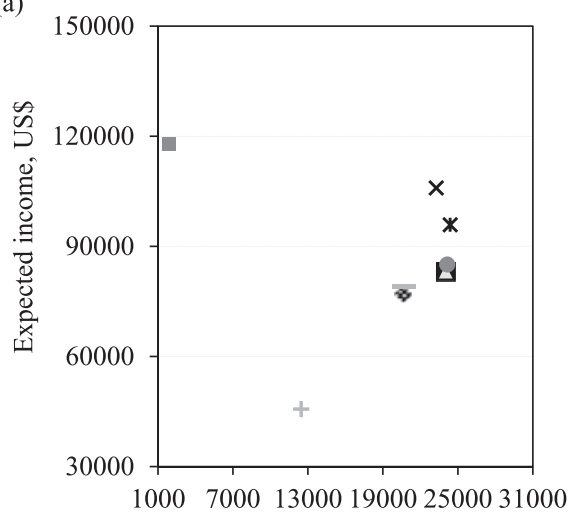

(b)

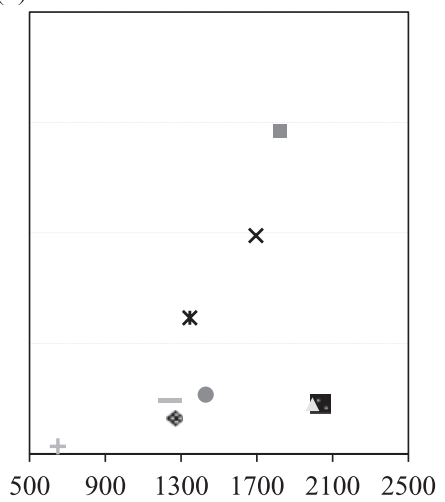

Variance of income, $10^{-4}$ US\$

Lowest MBI values: Highest MBI values:

\begin{tabular}{|c|c|c|}
\hline \multirow[t]{4}{*}{ BAU } & Eco-certification & * Eco-certification \\
\hline & - Carbon & $\times$ Carbon \\
\hline & $\$$ Pigovian tax & + Pigovian tax \\
\hline & - Combined & Combined \\
\hline
\end{tabular}

Figure 5. Cumulative expected and variance of income over 30 years for hardly (a) and extremely (b) risk-averse farmers under the scenarios of business-as-usual (BAU), and the lowest and highest market-based instrument (MBI) values

Note: Discount rate is $10 \%$.

of land-use change depending on the behavior of farmers in response to risk. Our study captures the variability of land-use incomes when addressing the performance of MBIs, and shows that the effectiveness of MBIs and provision of ecosystem services is influenced by temporal flexibility in the decision making of farmers, and the risks and associated attitudes of farmers. In comparison to the study from Brazil, Engel et al. (2015) found that uncertainty in future land-use returns influences the timing of forest conversion to annual crops. Consideration of flexibility in decision making over time adds value to agriculture and reduces the value of agroforest in contrast to the deterministic model (Frey et al., 2013). By considering temporal flexibility under uncertainty through the combination of a dynamic mean-variance model with a real options approach, we show conversion of agroforest to monoculture crops over the years. Such land-use change is a result of increase in profits from a delay option.

Considering the temporal flexibility and uncertainty in returns, the previously suggested premium levels of $1-5$ per cent for eco-certified agroforest rubber (Leimona, 2010) and US\$5 $\mathrm{tCO}_{2}^{-1}$ payments for stored C (Peters-Stanley et al., 2012) can be insufficient to reverse land conversion trends, especially for hardly risk-averse farmers. According to Leimona 
(2010), some companies are willing to pay premiums of up to 25 per cent for eco-certified rubber from agroforestry systems. But even these values may not lead to the desired conservation of agroforest. The model results show that, when implementing MBIs individually, the agroforest area is eventually converted to monoculture crops but with a lower conversion rate over years in contrast to the BAU scenario, i.e., the farmer delays conversion. Among MBIs the rate of change of agroforest into monoculture crops is lowest when farmers are taxed for $C$ emissions. Uncertainty in future returns necessitates a substantial increase in $\mathrm{MBI}$ values to avoid land-use change (Engel et al., 2015). We found that the most effective MBI is the combination of different MBIs with their fixed values. Our results with fixed MBI values contradict the findings of many studies that have identified specific MBI values for avoiding land-use change based on opportunity cost analyses and without consideration of a real options approach (e.g., Cacho et al., 2014). The model shows that for conserving agroforest over time the reward and tax values that are adjusted based on the opportunity cost are greater than fixed MBI values. This is due to a preference of riskaverse farmers for receiving and paying the more certain values over time. We show that the more risk-averse the farmer is, the less s/he prefers to do long-term planning and make investments in land uses with high uncertain returns, which reduces the investment value of monoculture. Accordingly, MBIs targeted towards extremely risk-averse farmers can achieve better aims of conserving sustainable land uses. At the same time, when there is no MBI, the establishment of monoculture crops while having mainly agroforest area may function as a risk-reducing strategy for the extremely risk-averse farmer.

Our assumption of fixed MBI values may be realistic due to the possible negotiations on MBI values (i.e., in advance long-term contracts) between buyers and sellers of ecosystem services. However, in such contracts, farmers might have lower flexibility in land-use decision making and may be bound to maintain a certain area of agroforest and thus enrollment in the $\mathrm{MBI}$ contract might be low. It is also important to consider that MBI values may fluctuate because of business cycles, uncertainty about future policies and land tenure rights. Moreover, it should be noted that during the time of data collection, oil palm was an infrequent land use due to the absence of a palm oil extraction mill in the study area. It is expected that farmers' decisions about whether to convert to oil palm plantations is also influenced by the establishment of a local mill. To address these issues, the MBIs need to be adjusted when economic and infrastructural conditions change.

Furthermore, according to van Noordwijk et al. (2012), it is unrealistic to expect any single price to emerge from ecosystem services that reflects their true value across scales. For example, area-based ecosystem services (e.g., C sequestration, biodiversity conservation) may have different discount rates relative to product-based markets (e.g., eco-certification). In addition, there are ecosystem services that can be valued in monetary terms and those that bear no exchange value (e.g., cultural). If they are considered in policy and decision making, the benefits from agroforestry can further increase. 


\subsection{Market-based instruments for farm incomes}

The impacts of MBIs on farmers' livelihoods can vary depending on their characteristics. The heterogeneity among farmers stems from differences in income level, employment status, knowledge, and attitudes regarding land-use management, among others. For instance, Dhakal et al. (2012) revealed that the forest policies in Nepal can have negative repercussions on employment and income of different rural people, and widen wealth inequality. Similarly, our study shows that under conditions of uncertainty the perception regarding risks influences the incomes of farmers. The hardly risk-averse farmer over the period of analysis completely converts agroforest to monoculture crops and subsequently earns higher income than the extremely risk-averse farmer. The extremely risk-averse farmer plans land uses in such a way as to hedge against risk through diversification by preferring mainly agroforestry and some area of monoculture crops. The diverse land-use allocation brings stability to farm production and is an important risk management instrument for farmers (Di Falco and Perrings, 2005). For example, Babu and Rajasekaran (1991) concluded that farm diversification through the agroforestry in India is a means of reducing the negative repercussions of income risks. In addition, it should be noted that the risk-aversion behavior of farmers depends on land tenure security (Engel et al., 2015), future prospects between gains and losses, and on the shift from risk taking to risk aversion that can be influenced by communication within populations.

The welfare benefits for risk-averse farmers differ depending on MBIs. Among the MBIs, although the tax-based instrument can be beneficial in reducing conversion of agroforest and maintaining provision of ecosystem services, it may put pressure on rural livelihoods. In contrast, the ecocertification premiums and $C$ payments increase the incomes of farmers, but farmers still convert a substantial area of agroforest into monoculture crops. The combined scenario is the most promising in conserving agroforest. It also brings the highest $\mathrm{CE}$ for farmers and reduces the difference in income levels between hardly and extremely risk-averse farmers. By targeting MBIs for poor farmers that are usually strongly averse to risks, MBIs can provide additional income generation for them and subsequently reduce the rural income inequality. This is due to land-use diversification, i.e., agroforestry, which reduces the income variability. MBI initiatives can also help farmers to manage income risk. The fixed levels of rewards and taxes result in definite revenues and costs, respectively, which reduce the income variance. Accordingly, fixed levels of MBIs can help to manage income risks of farmers, while among MBIs the eco-certification premiums and $C$ payments address improvement of incomes more than environmental concerns, and the reverse holds for the Pigovian tax. The combined scenario allows us to address risk management, income inequality and environmental conservation and thus is the instrument that results in the highest social welfare among the scenarios of our model.

Moreover, the actual land-use change is determined by farmers and their private decisions, and does not always reflect the full economic value of policies at the village, regional and countrywide levels. The scale issue is important because the effect of MBIs can vary across spatial scales 
(Busch et al., 2012). For instance, by increasing the scale of analysis, we may observe that the collected taxes to prevent conversion of agroforest return to farmers through subsidies, social payments or improvement of infrastructure. It may also happen that MBI rewards actually result in a decrease in welfare. According to Irawan et al. (2013), reward mechanisms such as REDD+ for $\mathrm{C}$ storage lead to public revenue losses at the district, provincial and national government levels in Indonesia. Moreover, the effects of MBI can be direct and indirect (Djanibekov et al., 2013). For example, farmers may not have sufficient household labor and may rely on hired labor to manage land uses. The maintenance of low labor demanding land uses such as agroforest frees up rural labor due to limited alternative employment opportunities and limited availability of arable land for crop cultivation, which may reduce the income of rural labor. Hence, in future research when investigating MBIs to conserve land uses, it is vital to increase the scale of analysis and consider various actors that are directly and indirectly involved in land-use change under conditions of uncertainty.

\section{Conclusions}

This study evaluates the effectiveness of different MBIs for conserving agroforest rubber production systems while considering associated income risks and farmer attitudes towards such risks. For this we develop a dynamic mean-variance programming model that combines the real options approach and considers different risk-aversion levels in farm decision making. Model results show that because of risks and their influence on farmers' land-use choice, the farm incomes and agroforest conservation outcomes vary. A hardly risk-averse farmer chooses more profitable but less certain and unsustainable land-use practices such as oil palm and rubber monoculture. The higher the risk aversion of farmers is, the larger the area of agroforest that is maintained, because this production system generates lower income variance. However, additional incentives in the form of MBIs are still required to prevent conversion of agroforest over the years. We identified that no single MBI can address the complete prevention of converting agroforest to monoculture systems. Among MBI policies, the combination of eco-certification premiums, $\mathrm{C}$ payments and Pigovian taxes results in the best conservation outcome. Moreover, the introduction of slight values of MBIs may already have substantial impacts on the extremely risk-averse farmer for maintaining agroforest, while the hardly risk-averse farmer most likely reduces the conversion of agroforest into monoculture crops only with combination and high values of MBIs. Currently suggested MBI values appear to be insufficient to incentivize farmers to avoid conversion of agroforest into monoculture crops, and such an aim can only be achieved at higher values of MBIs. In addition, fixed MBI rewards and taxes stabilize incomes and costs, respectively, and thus reduce variance of income risks. Introducing a combination of MBIs also improves incomes and reduces income inequality between hardly and extremely risk-averse farmers. Thus, we suggest that, under conditions 
of uncertainty, it is important to consider heterogeneous farmers and aim MBIs towards farmers that are susceptible to risks.

\section{Supplementary material and methods}

To view supplementary material for this article, please visit https://doi. org/10.1017/S1355770X16000310.

\section{References}

Alvarez, L.H.R. and E. Koskela (2006), 'Does risk aversion accelerate optimal rotation under uncertainty?', Journal of Forest Economics 12(4): 171-184.

Anderson, J.R. and J.L. Dillon (1992), Risk Analysis in Dryland Farming Systems, Rome: Food and Agriculture Organization of the United Nations.

Babu, S. and B. Rajasekaran (1991), 'Agroforestry, attitude towards risk and nutrient availability: a case study of south Indian farming systems', Agroforestry Systems 15: 1-15.

Baumgärtner, S. and M.F. Quaas (2010), 'Managing increasing environmental risks through agrobiodiversity and agrienvironmental policies', Agricultural Economics 41: 483-496.

Blackman, A. and M.A. Naranjo (2012), 'Does eco-certification have environmental benefits? Organic coffee in Costa Rica', Ecological Economics 83: 58-66.

Budidarsono, S., L. Joshi, and G. Wibawa (2010), 'A profitability assessment of smallholder rubber agroforestry systems in Jambi, Sumatra, Indonesia', in B. Leimona and L. Joshi (eds), Eco-certified Natural Rubber from Sustainable Rubber Agroforestry in Sumatra, Indonesia - Project Final Report, Bogor: World Agroforestry Centre.

Budidarsono, S., A. Rahmanulloh, and M. Sofiyuddin (2012), 'Economic assessment of palm oil production', Technical Brief No. 26, World Agroforestry Centre (ICRAF), Bogor.

Busch, J., R.N. Lubowski, F. Godoy, et al. (2012), 'Structuring economic incentives to reduce emissions from deforestation within Indonesia', Proceedings of the National Academy of Sciences 109: 1062-1067.

Cacho, O.J., S. Milne, R. Gonzalez, and L. Tacconi (2014), 'Benefits and costs of deforestation by smallholders: implications for forest conservation and climate policy', Ecological Economics 107: 321-332.

Castro, L.M., B. Calvas, P. Hildebrandt, and T. Knoke (2013), 'Avoiding the loss of shade coffee plantations: how to derive conservation payments for risk-averse land-users', Agroforestry Systems 87: 331-347.

Center for Statistics Bureau of Bungo District (2012), Statistical Yearbook of Bungo District, Jambi Province, Sumatra: Center for Statistics Bureau of Bungo District.

Dhakal, B., H. Bigsby, and R. Cullen (2012), 'Socioeconomic impacts of public forest policies on heterogeneous agricultural households', Environmental and Resource Economics 53: 73-95.

Di Falco, S. and C. Perrings (2005), 'Crop biodiversity, risk management and the implications of agricultural assistance', Ecological Economics 55: 459-466.

Dixit, A.K. and R.S. Pindyck (1994), Investment under Uncertainty, Princeton, NJ: Princeton University Press.

Djanibekov, U. and A. Khamzina (2016), 'Stochastic economic assessment of afforestation on marginal land in irrigated farming system', Environmental and Resource Economics 63(1): 95-117.

Djanibekov, U., N. Djanibekov, A. Khamzina, A. Bhaduri, J.P.A. Lamers, and E. Berg (2013), 'Impacts of innovative forestry land use on rural livelihood in a bimodal agricultural system in irrigated drylands', Land Use Policy 35: 95-106. 
Engel, S., C. Palmer, L. Taschini, and S. Urech (2015), 'Conservation payments under uncertainty', Land Economics 91(1): 36-56.

Frey, G.E., D.E. Mercer, F.W. Cubbage, and R.C. Abt (2013), 'A real options model to assess the role of flexibility in forestry and agroforestry adoption and disadoption in the Lower Mississippi Alluvial Valley', Agricultural Economics 44: 73-91.

Hardaker, J.B., R.B.M. Huirne, J.R. Anderson, and G. Lien (2004), Coping with Risk in Agriculture, London: CABI.

Irawan, S., L. Tacconi, and I. Ring (2013), 'Stakeholders' incentives for land-use change and REDD+: the case of Indonesia', Ecological Economics 87: 75-83.

Kassar, I. and P. Lasserre (2004), 'Species preservation and biodiversity value: a real options approach', Journal of Environmental Economics and Management 48: 857-879.

Knight, F.H. (1921), Risk, Uncertainty, and Profit, Boston, MA: Hart, Schaffner \& Marx/Houghton Mifflin.

Koskela, E., M. Ollikainen, and T. Pukkala (2007), 'Biodiversity policies in commercial boreal forests: optimal design of subsidy and tax combinations', Forest Policy and Economics 9: 982-995.

Koundouri, P., C. Nauges, and V. Tzouvelekas (2006), 'Technology adoption under production uncertainty: theory and application to irrigation technology', American Journal of Agricultural Economics 88: 657-670.

Leimona, B. (2010), Eco-certified Natural Rubber from Sustainable Rubber Agroforests in Sumatra, Indonesia: Project Profile Results, Bogor: World Agroforestry Centre (ICRAF).

Margono, B.A., S. Turubanova, I. Zhuravleva, et al. (2012), 'Mapping and monitoring deforestation and forest degradation in Sumatra (Indonesia) using Landsat time series data sets from 1990 to 2010', Environmental Research Letters 7(3): $1-16$.

Martínez-Sánchez, J.C. (2008), 'The role of organic production in biodiversity conservation in shade coffee plantations', PhD thesis, University of Washington, Seattle, WA.

Ministry of Agriculture of Indonesia (2012), Yield and Price Values in Land Use Production, Jakarta: Directorate General Ministry of Agriculture.

Musshoff, O. (2012), 'Growing short rotation coppice on agricultural land in Germany: a real options approach', Biomass and Bioenergy 41: 73-85.

Peters-Stanley, M., K. Hamilton, and D. Yin (2012), 'Leveraging the landscape: state of the forest carbon markets 2012', Washington, DC: Ecosystem Marketplace.

Purnamasari, R., O. Cacho, and P. Simmons (2002), 'Management strategies for Indonesian rubber production under yield and price uncertainty: a bioeconomic analysis', Agroforestry Systems 54: 121-135.

Rahayu, S., B. Lusiana, and M. van Noordwijk (2005), 'Above ground carbon stock assessment for various land use systems in Nunukan, East Kalimantan', in B. Lusiana, M. van Noordwijk, and S. Rahayu (eds), Carbon Stock Monitoring in Nunukan, East Kalimantan: A Spatial and Modelling Approach', Bogor: World Agroforestry Centre (ICRAF) Southeast Asia, pp. 21-34.

Ramirez, O.A., E. Somarriba, T. Ludewigs, and P. Ferreira (2001), 'Financial returns, stability and risk of cacao-plantain-timber agroforestry systems in Central America', Agroforestry Systems 51: 141-154.

Regan., C., A.B. Bryan, J.D. Connor, W.S. Meyer, B. Ostendorf, Z. Zhu, and C. Bao (2015), 'Real options analysis for land use management: methods, application, and implications for policy', Journal of Environmental Management 161: 144-152.

Tata, H.L., M. van Noordwijk, and M. Werger (2008), 'Trees and regeneration in rubber agroforests and other forest-derived vegetation in Jambi (Sumatra, Indonesia)', Journal of Forestry Research 5: 1-20. 
Tomich, T.P., D.E. Thomas, and M. van Noordwijk (2004), 'Environmental services and land use change in Southeast Asia: from recognition to regulation or reward?', Agriculture, Ecosystems \& Environment 104: 229-244.

van Noordwijk, M., B. Leimona, R. Jindal, et al. (2012), 'Payments for environmental services: evolution toward efficient and fair incentives for multifunctional landscapes', Annual Review of Environment and Resources 37: 389-420.

van Noordwijk, M., V. Bizard, P. Wangpakapattanawong, H.L. Tata, G.B. Villamor, and B. Leimona (2014), 'Tree cover transitions and food security in Southeast Asia', Global Food Security 3: 200-208.

Villamor, G.B. (2012), 'Flexibility of multi-agent models for rubber agroforest landscapes and social response to emerging reward mechanisms for ecosystem services in Sumatra, Indonesia', PhD thesis, Ecology and Development Series No. 88, University of Bonn.

Villamor, G.B. and M. van Noordwijk (2011), 'Social role-play games vs individual perceptions of conservation and PES agreements for maintaining rubber agroforests in Jambi (Sumatra), Indonesia', Ecology and Society 16: 27.

Villamor, G.B., R.G. Pontius Jr., and M. van Noordwijk (2014a), 'Agroforest's growing role in reducing carbon losses from Jambi (Sumatra), Indonesia', Regional Environmental Change 14(2): 825-834.

Villamor, G.B., Q.B. Le, U. Djanibekov, M. van Noordwijk, and P.L.G. Vlek (2014b), 'Biodiversity in rubber agroforests, carbon emissions, and rural livelihoods: an agent-based model of land-use dynamics in lowland Sumatra', Environmental Modelling \& Software 61: 151-165

World Bank (2015), 'Annual population growth data', [Available at] http://data. worldbank.org.

Wunder, S. (2008), 'Payments for environmental services and the poor: concepts and preliminary evidence', Environment and Development Economics 13(3): 279-297. 